U. S. DEPARTIENT OF CORIERCE NATIONAL BUREAU OF STINDARDS

WASHINGTON

$\operatorname{March} 15,1941$
Letter

Circular

$\mathrm{I} C-641$

(Supersedes

LC 494)

Publications by Merbers of the Staff of the National Bureau of Standards, together with a list of Federal specifications.

CONIERTS

Page

Part I - Technologic Paperis $(\mathrm{T}) \ldots \ldots \ldots \ldots \ldots \ldots \ldots$

Part II - Research Papers (RP) .................

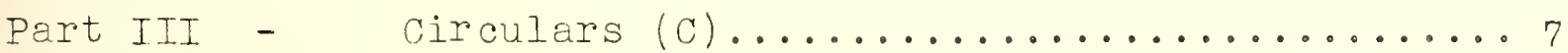

Part IV - Letter Circulars (LC)..............

Part $\mathrm{V} \quad-\quad$ Federal Specifications (FS)..............

Part VI - outside Publications................. 8

\title{
GEINERAL INFORNATION
}

Some of the publications in this list have appeared in the regular series of publications of the Bureau and others in various scientific and technical journals. Unless specifically stated, papers are not obtainable from the National Bureau of Standards.

Where the price is stated, the publication can be purchased from the Superintendent of Docurients, Governrent Printing orfice, Washington, D. C. The prices quoted are pro delivery to addresses in the united states and its territories and possessions and in certain countries which extend the franking privilege. In the case of all other countries, one-third the cost of the publication should be added to cover postage. Rerittances should be made either by coupons (obtainable from the Superintendent of Documents in sets of 20 for $\$ 1.00$ and good until used), or by check or money order peyable to the "Superintendent of Documents, Government Printing office," and sent to him vith order. Letter circulars are obtainable, without charge, Prom the Bureau. Publications marked "OP" are out of orint, but, in Eeneral, nay be consulted at technical libraries.

For papers in other scientific or technical journals, the name of the journal or of the organization publishing the article is given in abbreviated form with the volune number (underseored), page, and year of nublication, in the order named. 
serial letters are used to desicnate tine several series of Bureau oublicstions:

$$
\begin{gathered}
T=\text { "mechnolosic papel". TI to T370. This series } \\
\text { Was superseded by the "Bureau ol Standardis } \\
\text { Joumal of Research" in } 1928 .
\end{gathered}
$$

$R P=$ "Research Paper." These are reprints of articles anpearin in the "Bureau of Standards Journal of Fesearch" and the "Journal of kesterch of the rational Bureau of Standards," the latter beine the title of tiis periodicel since July 1934 (volume 13, number 1).

$C=$ "Circular."

LC = "Iteter Circuler."

Circular C24 and supnlements, the complete list of the Bureau's nublications (.901-1936), is sold b: the Superintendent of. Documents for 55 cents. innouncerent of nes jublications is made each month in the mechnical Ners Bulletin wich is obtainable by subscription at 50 cents ner year.

\section{PART I. - TECTIOLOGIC PHPSRS}

Geries Price

Tests of the absorntive and nermeable properties 13 $\mathrm{OP}$ of portland cerient mowters an concretes, torether vith tests of dampproofine and raterproofino comounds and materials. R. J. Tis and P.it. Bates. Tech. Din. BS I, (1910-1: $)$. The effect himhressure stem? on the crushing T5 $O P$ strencth f nortina cersent ind concrete. R.T. Wi. Tes. Pan. BS I, (1910-13).

Action of the salts in alieli water cina sea water TIz OP on cerent. P. I. Bates, i. Juilips and

R. T. Tir. Tenh. Pap. Bj ?, (121"-14).

Variation in results of sitving with stunära cerent sieves. P. T. ric and T. C. Pearson. Tech. T29 DP pep. B3S $(1911-10)$.

Standeraization of ITo. DOO cerent sieves. K. T. T42 OP "Tif and T. C. Pearsan. Toch. Pun. BJ 
Series Price

Value of the hich pressure steam tests of port- T47 OP lana cement. R. T. Wi and H. A. Davis. Tech. Pap. BS 5, (1914-15).

An air analyzer for deteminine the fineness of T48 OP ceruent. J. C. Pearson and W. I. Sligh. Tech. Pap. BS 5 , (1914-15).

Properties of the calcium silicates and calcium T78 $\mathrm{OP}$ aluminate occurring in nomal portland centent. P. H. Bates and A. Hein. Tech. Pap. BS 8, $(1916-17)$.

The properties oì portland cement having a high Tlod $\mathrm{OP}$ magnesia contert. F. H. Bates. Tech. Pap.

BS 9, $(191 \ell-17)$.

Dffect of cal as an accelerator of the hardening T174 $O P$ of portiand cement rixtures. P. Ij. Youn . Tech. Pap. BS 14, (1920-21).

Cementing qualitjes of the calcium alumintes. T197 $\mathrm{OP}$ P. H. Bates. Tech. Pap. BS 15, (1921)。

Tests of caustic manesia made frorn masnesite from several sources. P. H. Bates, R. IT. Young and P. Rapp. Tech. Pap. BS 17, 529 $(1322-24)$.

T239

$\mathrm{OP}$

\section{PART II. - RESEARCH PAPERS}

Reaction of water on calcium aluminates. L. S. Wells. BS J. Research 1, 951 (1928)

Series Price RP34 $O P$

The sulphoaluminates of calciur. W. Lerch, KP5 4 $10 \not$ F. . Ashton and R. I. Bogue. BS $J$. Research 2, $715(1928)$.

Influence of maknesia, ferric oxide, und soda RP13: $C P$ upon the temperature of Iiquia forration in certain portland cement mixtures. H. C. Hansen. BS T. Research 4, 55(1930)。

The X-ray method applied to a study of the con- RP233 stitution of portland cerient. $T$. T. Brownilier and R. H. Bogue. BS J. Research 5, $813(1930)$.

Determination of mannesium in portland cerent RP265 and similar materials by the use of 8-hydroxyquinoline. J. C. Redrond and $\mathrm{H}$. A. Bright. BS J. Research 6, 113(1931). 
The decomposition of tricalcium silicete in the

RP381

$5 \not$

tempereture ranse, 1,000-1,300 ${ }^{\circ}$. I. T.

Carison. BS T. Restirch 7, $893(1331)$.

The Syatel, CaO-Nar C-Al, O3. I. II. Bromniller

and F. H. Boruc. BS J. Research 8, 289(1932)

P.P4.14

5 t:

The system: CaO- $\mathrm{B}_{2} \mathrm{O}_{3} \cdot \mathrm{E} \cdot \mathrm{T} \cdot \mathrm{Carlson}$.

BS J. Research 9-, 82E (1932).

KP510

56

The precipite ion and titration of magnesiur

RP569

$5 t$

oxyauinolate in the presence of calcium

cxilate, shl its apklication in the cinalysis

of portiand cement and similar silicetes.

T. C. Redmond. BS J. Research 10, 823 (1933).

The activity coeficiunts of hydroxyl ion in

solutions of celetur hydroxide at $30^{\circ} \mathrm{c}$.

F. P. Flint and I. S. HeIIS. BS J. Research II, $163(1933)$.

Heat of hydration of nortland cement pastes.

Werch and R. H. Bopue. T. Reseerch NBS

12, $645(1934)$.

Study of the syoter CaC-SiO2- $\mathrm{H}_{2} \mathrm{O}$ at $30^{\circ} \mathrm{C}$ and the

RP 587 reaction of water on the anhydrous calcium silicates. F. R. Flint and L. J. Mells. J. Research IJBS 12, 751 (1934).

Investipation of corrercial masonry cements. J. S. Rogers and R. I. Blaine. J. Research NBS 13, $811(1934)$.

Effect of ranulometric corposition of cernent on the properties of pastes, mortis, and concretes. To irthur swenson, Jacey r. Tagner, and George I. Picrian. JoResearoh Ths lis, $419(1935)$.

Effect of calcium chlorile on portland cerents and concretes. Priul Rapp. T. Research NBS $14,439(1935)$.

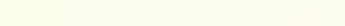

Behuvior of hich-early-streneth cement concretes and rortars under various terperature inà humidity conditions. Iouis Schumen ana Edward A. Pisanis. T. Rasearch NBS I4, $723(1935)$.

A study for the preparation of e snecification for hich-early-strenth portinn cement. G. Runert Giuse. I. Reseanch NBS 15, 421(1935). 
Studies of the quaternary system CaO-ligo-2CaO. $\mathrm{SiO}_{2}-5 \mathrm{CaO} .3 \mathrm{Al}_{2} \mathrm{O}_{3}$. H. F. Mcrurdie and Herbert Insley. J. Research NBS 16, 407(1930).

Effects of partial prehydration and different curing terneratures on sore of the properties of cement and concrete. F. B. Hornibrook, G. L. Talouser, und C. H. Jumper. J. Research NBS 10, $487(1936)$.

A rapid method for the detemination of silica in portland cent. Edwin E. Ifuczkowske. J. Research NBS 16, 549(1936).

Determination of sulphuric anhydride in portland cement by means of the lagner turbidineter. Robert B. Rudy. J. Research PiBS 16, 555(1930).

Distribution of comounds in portland cement. $e^{T}$. Arthur Swenson and P. Flint. T. Research NBS 1?, $231(1936)$.

Structural characteristics of some constituents of portland cement clinker. Herbert Insley. J. Research IBS I? , 353(1935).

The syster lime-boric oxide-silica. I. P. Plint and Lansine S. Vells. J. Research ITBS I7, $727(1936)$.

Determination of sulphur occurrins as sulphide in portand conent. Harry A. Brisht. J。 Research ITSS 18, 137(1937).

Studies on a portion of the suster: $\mathrm{CaO}-\mathrm{Al}_{2} \mathrm{O}_{3}-$ $\mathrm{Fe}, \mathrm{O} 3$. Howard $\mathrm{F}$. IIcliturdie. J. Research" ITBS 18, $475(1937)$.

Method for approximating the glass content of portland cenent clinker. Wiliar Lerch end Lorrin T. BrowmilleI. J. Kesenich IVBS 18, $609(1937)$.

Hyäration of magnesia in dolomitric hydrated lines and putties. L. S. WeIls and R. Waylor. J. Research IBS 19, 215(1937).

Approximate glass content of commercial cement clinker. Tr. Jerch. J. Research ITBS 20, $\operatorname{RP8915} 5 \not$ RP893 
minor constituents in portland cement clinker. RP1074 10Æ

H. Insley and $y_{\text {. }}$. liciurdie. J. Research

INBS 2C, $173(1338)$.

Heats of hydration and transition of calciuri

sulfate. E. S. Nevrian and I. S. Mells.

RPI107

$5 \not$

J. Research NBS 20, $825(1938)$.

Studies of heat of solution of calcium and

RPIIミI

$5 \not 2$

magnesium oxides and hydroxides. r.

Tajor and L. S. Welis. J. Research IJBS

$21,133(1938)$.

Effect of glass content unon the heat of hydration of portland cements. Th. Ierch.

T. Research IJBS 21, $235(1938)$.

Phase equilibria studies on mixtures of the

RPI131

RPI127 I0\%

compounds $4 \mathrm{CaO} \cdot \mathrm{Al}_{2} \mathrm{O}_{3} \cdot \mathrm{Fe}_{2} \mathrm{O}_{3}-2 \mathrm{CaO} \cdot \mathrm{Fe}_{2} \mathrm{O}_{3}-\mathrm{K}_{2} \mathrm{O}$.

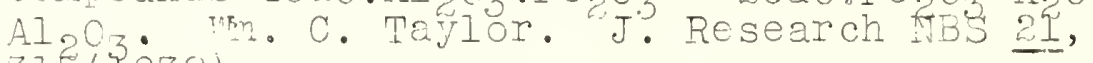
$315(1938)$.

Relation of cornosition and heats of solution of nortiand cement clinker. Herbert Insley,

RP11.35

Einar P. Flint, tâin S. ITewan and T. Erthur

Swenson. J. Research IrBS 21 355(1938)。

Formation of hydrated calciur silicates at

elevated temperatures and pressures. E. P.

Flint, L. S. Mells and I. F. Mcrurdie.

T. Research NBS II, $177(1938)$.

Wear resistance of portland cenent floors.

L. Schuman und Tohn Tucker, Jr. J. Research IIBS 23, $549(1939)$.

Application of vibrators for measuring mortar consistency and febricating nortar cubes.

R. I. Blaine and J. ruclej, Ir. J. Resesrch NBS 24, $(1940)$.

The nature of the glass in portind cenent clinker. Ir. Insley. J. Researoh IJBS 25, $\therefore 95(1940)$.

Studies on the system line-perric oxide-silica.

RP1340

I.. D. Burdick. J. Rk search TBS 25, 395 (1940). 
PART II - RESTARCII PAPERS (Continued)

Series Price

Hydrothemal and $\mathrm{X}$-ray studies of the garnetRP1355 10ф

hydrogarnet series and the relationship

of the series to hydration products of

portland cement. E. P. Flint, Howard F.

Nonurdie, and Lansing. S. Wells. J. Research

NBS 26, $13(1941)$.

Effect of heat treatment and cooling rate on the RP1358 $10 \%$ microscopic structure of portland cerent

clinker. George W. Ward. J. Research

IJBS 26, 49(1941).

PART III. - CIRCUIARS

Series Price

Materials for the household (nontechnical inforration on use of cement). Cir. BS

C70

$50 \varnothing$ (1917).

Caustic maonesia cement. Cir. BS (1922).

C135

$O P$

stucco investigations at the Bureau of standards

C311 OP with recommendations for portland cement stucco construction. Cir. BS (1926).

PART IV. - IETTEE CIECULARS
(Free on apnIication to the Bureau)

The development of standard sieve specifications LC3II in the United States. (1931).

Policy of the IJational Bureau of Standards vith IC544 regard to tests for outside agencies. (1939).

Standard specifications for sieves. (1940). IC584

Building materials, building standards, home

building: Publications of the National Bureau of Standards (list). (1940).

LC592

\section{PAPT $V \cdot$ - TEDERAI SPECIFICATIONS}

The specifications listed below are issued by the Federal Snecisications txecutive Comittee, Procurerient Division Building, Washington, D. C. Copies may be secured from the Superintendent of Documents, Government Printing Office, this city, at the prices indicated: 


\section{PAPT V. - FEDERAT SPECIEICATICIS (cont'd)}

cement; rennesia

cenent; pipe-coverine

cenents, hydraulic; ceneral snecifications

knethods for sambine, inspection, and testins:

Cenent; rasonry

Cement: portland.

Cement; portlanc, hish-early-strength.

Cement; portland, moderate-heat-of-hardening.

Cement: portiund, pozzolana

Cenent; portland, sulphate-resistins

Sieves; standard, testing?
Series Price

IEH-:-61 54

HII-P-380ंa $5 \not$

$\begin{array}{lr}S S-C-158 & 10 \not \\ S S-C-181 b & 5 \not \\ S S-C-191 a & 5 \not \\ S S-C-201 & 5 \not \\ S S-C-206 & 5 \not \\ S S-C-208 & 5 \not \\ S S-C-211 & 5 \not \\ \text { FR-S-366 } & 5 \not\end{array}$

\section{PART VI. - CUTSIDE PUBLIC TIOIS}

The articles listed below are not icr distribution or sale by the Government, but may be consulted at most laret I braries or in sore cases nay be purchased ajrently from the publishers.

The effect of hish pressure sterm on the crushing strength of nortland cement rorter ind concrete. R. J. Mif. Proc. Am. soc. Mestine raterials (Amerdoan Society for Testine Paterials, co J. Broad st., Philadelphia, Ps.), Il, $580(1911) ;$ a 1 so Tech. Pap. Ls, T5, I, (1910-12).

Present status of iron ore cerent. P. H. Bates. T. Prat. Awen. Cement tsers (Airrican concrete Institute, 7400 Second Boulevard, Detroit, Iich.), $500(1912)$.

Actine of the salts in alkali weter and jeu vatur on cement. R. T. Wie and B. H. Bates. T. Eranklin Inst. (Journal cf the Tranklin Institite, Noth and Parivay, Phila., Da.l, 175, $65(1925)$ : also meoh. Pap. 3S, TIR, 过 (191:-14).

The constitution cl nortikna cercnt. P. II. Bates. J. itat. Assn. Cement Users, 3is (1913). 
Errors in the methods of deteminine the time of setting of cement. C. Thilliams. Proc. Am. Soc. Testing laterials, 14, Part II, 172(1914).

Time of setting of cerent. G. Milliams. Proc. Ar. Soc. Testing liaterials, 14, Part II, 200(1914).

Properties of portland cenent having a high ligo content. P. H. Bates. Proc. Am. Concrete Inst. (American Concrete Institute: 740C Second Blvd., Detroit, Iich.), 10, $470(1914)$.

Some properties of white portland cement. P. I. Bates. J. Ar. Ceram. Soc. (American Ceranic Society, 2525 Iv. Hich St., Columbus, ohio), le, 551 (1914).

Some further results obtained in investigations of the properties of portlera crient having a high reg content. P. H. Bates. Fyoc. Am. Concrete Inst. (Anerican concrete Institute, 7400 Secord Blva., Detroit, Iijch.), ll, (1915).

The effect of fine grinding and a higher $\mathrm{SO}_{3}$ content upon the physical properties of portland cerient. P. H. Bates. Proc. Am. Soc. Testing Haterials (Arerican Society for Mesting Materials, 260 s. Broad St., Phila., Pa.), 15, Part. II, $126(1915)$.

Process and apnaratus for separatine and andyzing manular materials. Patent 1,186,525. U. S. Patent Office, Tashington, I. C., June 8, 1916. (Price 10 cents).

What is the trouble with concrete in seavaters F. J. Mig and Lewis R. Ferguson. En. News-Recora - Series of five articles (IncGraw-Hill Publishing Co., Inc., 330 . I. 4hd St., lvew York, IT. Y.), Sept. 1917 .

The hydraulic properties of the calcium aluninates. P. II. Bates. T. Am. Ceran. Soc., I, 079 (oct. 1918).

cerents producing guick hardening concretes. P. H. Bates. Proc. Am. Soc. Testing itaterials, 1S, part II, 429(1919).

Specifications for the U. S. Standard sieve series. J. C. Pearson. Proc. Ar. Concrete Inst., 16, 49(1920).

Effect of age of test pieces in sounaness tests of portland cerient. J.R. Dwrer. Concrete - Cement Rili Edition (Concrete Publishing Co., 400 T. Madison St., Chicago, Ill.), 17, $87(\mathrm{D} \in \mathrm{C} .1920)$.

Shrinkage of cement mortars and its importance in stucco construction. J. C. Pearson. Proc. im. Concrete Inst., 17, $133(1921)$. 


\section{PART VI. - OTSEIDE PUELICAIIOISS (Continued)}

Time of set of concrete. Watson Davis. Proc. Am. Soc. Testinc liraterials, 2l, Part II, 995(1921).

Relation between tensile and comressive strengths of cerent mortars. T.R. Dwyer. Concrete - Cerent rill Edition, 18, $123($ Tune, 1921).

Plastic magnesia cements. P. H. Bates and FoJ I. Young. J. An. Ceram. Soc., 4, 570 (July 1921).

The application of the fundamental mowledge of portiand cement to its manufacture ana use. P. I. Bates. I. Franklin Inst. (Pranklin Institute, 20th and Parkway, Phila., Pa.), 193, 289(Itar. 1922).

Inspection of portanc cement. J. R. Dviter and Roy i. Young. Concrete (Concrete Publishing Co., 40C V. I'adison St., Chicaso, Ill.), 2l, fur. and Sept. 192.

reed of research in the portland cement industry. P. H. Bates. Chem. riet. Mn. (Chemical and retallurgeal Ineineerins, IncGrav-Hill publishing Co., 330 W. 42d St., NTew Vork, I. Y.), 29, 462(Ax\&. 3C, 1992).

What prope ties and methods of rakins portand cerient need further investigation? P. H. Bates. Proc. Ar. Soc. Testing raterials, (Americin Society for Testing Iiaterials, 260 S. Broad St.: Philadelphia, Pa.), 23, Part II, löo(1923).

Late data on fine crindins and aditional $\mathrm{SC}_{3}$ to cements. P. H. Bates. Proc. Am. Soc. Festing iaterials, 23, Part II, $248(1923)$.

Discussicn on the "ieanins and nicroscopic reasurement of averame particle size." J. C. Pearson. J. in. Ceram.

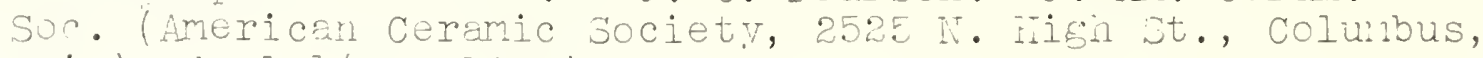
onio), $\underline{6}, 121($ Iay loż).

The possibility of immovine hydraulic cerents. P. I. Bates. Proc. Portian A Cerent Assn. (Portiana Cement Issociation, 33 West Grand Ave., Chicaro, Ill.), lay nl, 1923.

Discussion of aluminate cerent-portinc cerent. P. ... Bates. Proc. Am. Concrete Inst. (imerican concrete Institute, 7400 second Blvd., Detroit, Zich.), 20, 355(1924).

ITev process of making him alumina cornent. P. H. Bates. Rock Products (Mraderress Publishinf Corn., 205 W. Vacker Drive, chicaso, Ill.), Iay 30, 1925. 
PART V1.- OUTSIDE PUBTICATIONIS (Continued)

Fine grinding of cement increases strenctl of concrete. Morris Temin and F. Slich. Concrete, 27, 47 (Sept: $1925)$.

Dortland cement research. R. H. Bogue. Proc. Ar. Soc. Testing Materials, 26, Part II, 403(1920).

High alumina hydraulic cements. P. H. Bates. Ind. \& Eng: Chem. (Industrial and In ineerine Chemistry, liills Bldg., Mashinmton, D. C.), 18, 554(June 1926).

A diest of the literature on the constitution of portland cement clinker. R. H. Bogue. Concrete, July l925 to Feb. 1927.

Studies on the syster CaO- $\mathrm{Fe}_{2} \mathrm{O}_{3}-\mathrm{SiO}_{2}$. W. C. Hansen and $\mathrm{h}$. $\mathrm{H}$. . Bogue. T. Ar. Cher. Soc. '(Anerican Cherical society, The ohio State University, Coluribus, ohio), 48, l2ul(1020).

The determination of uncombined lime in portland cenent. It. Lerch and R. H. Bogue. Ind. E Eng. Cher. (Industrial and Engineering Chemistry, rills BIdg., Wasington, D. C.), 18, $739(1920)$.

Long time tests of hish magnesia cements. P. if. Bates. Proc. Am. Soc. Testinc Taterials (American Society for Testing liaterials, $260 \mathrm{~s}$. Broad St., Philadelphia, Pa.), 27, Part II, $324(1927)$.

Portlana cerent in concrete engineering. R. H. Bogue. Proc. Am. Concrete Inst. (Anerican Concrete Institute, 7400 Second Blvd., Detroit, Mich.), 23, 355(1927).

Why time is a factor in the study and use of cement. P. H. Bates. Proc. Am. Concrete Inst., 23, $436(1927)$.

The preparation and optical pronerties of calcium hydroxide crystals. F. A. Ashton and Raymond Milson. Am. J. Sci. (American Journal of Science, New Faven, Conn.), 13, 209 $(1927)$.

Studies on the system CaO- $\mathrm{Al}_{2} \mathrm{O}_{3}-\mathrm{SiO}_{2}$ : The composition of

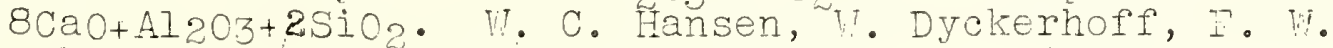
Ashton, and R. Hocue. J. Phys: Chem. (Journal of Physical Cheristr, Willism \& Wilkins co., Baltimore, Ia.), 31, 607 (1927); Rock Products (Tradenress Publishing Corp., $\overline{205}$. Macker Drive, Chicago, II1.), 30, April 16, 1927. 


\section{PAPT VI. - OUTSIDE PUTLICATIOIS (continued)}

The nreparation of optically clear selenium for use in inaex media. I. T. Brommiller. Ar. Mineral. (Aierican Mineralopical Society or America, U. S. Geological Survey, Hashinston, D. C.), In, $4.3(1927)$.

X-rar diffraction measurements on some of the nure compounds concerned in the study of portland cerlent. E. H. Harrington. Ar. J. Sci., 13, $467(1927)$.

The nresent status of portland cerent and the possibilities of super cements. P. I. Bates. Rock Products, 30, 77 (Dec.1927).

The combination of liric in poxtland cement compounas. - Preliminary investiotion. C. Tansen and k. Bogue. Ind. \&, EnE. Chem., 19, 1260(1227).

Studies on the hydrolysis of compounds wich ray occur in portiand cement. Terch and R. Hogue. J. Phys. Cher., 31, $18207(1827)$.

cerent as a factor in the workability of concrete. P. H. Bates and J.R. Dwer. Proc. Am. Concrete Inst., 24, 43(1928).

Irotes on the profuress of sone studles of the crazing of portiand cement mortars. P. H. Bates and C. I. Tumper. Proc. Ar. Concrete Inst., 2느, $179(1928)$.

Limes: structural cements, end plasters. P. H. Bates and J. ... Porter. Sxrvey Ar: Chem. (Survey of American Chenistry, ITational Fesearch Council, Tashinkton, D. C.), Third Annual, (1928).

Further stukjes on portland cement comounds by the X-ray diffraction method. 'T. C. Hansen. t. M. Ceran. Soc. (American Ceraric Society, 2525:. Hich St., Columbus, (hio), II, 68(teb. 1988).

A disest the the ziterature on the nature of the setting and hardenine processes of portland criert. Bocue. Rocis Products (Tradeoress Phbishin Corp., 05 W. Tacker Drive, Chicago, Ill.), Way to Sept. .282).

Hodem cernts - A stuuy of the characteristics of the hydraulio cerentis of today. P. F. Bates. InE". Nev's-Record (Ineineering NETS-Record, licGret-Hili Publishing Co., 330 l. I2nd st., NeV: Vork, IT. Y.), I00, 887 (Tune 7, 1828); 932 (June I4, $19.8)$. 


\section{PAET VI.- OUISIDE PUBIICARIONS (Continued)}

studies on the system calcium oxide-alumina-ferric oxide. Y. C. Iransen, L. T. Brommilier, and F. I. Bopue. J. Am. Cher. Soc. (Arerican Chemical Society, whe Ohio State University, columbus, Ohio), 50, $396(1.928)$.

Tquilibrium studies on alumins and ferric oxide combinations of these with manesia and calcium oxide. I. C. Hansen and L. T. Brommiler. Ar. J. Sci. (American Joumal of Science, $\mathbb{N}$ Tew Haven, Conn.), 15, $225(1928)$.

Phase equilibria in the systeri $3 \mathrm{CaO} \cdot \mathrm{SiO}_{2} \cdot \mathrm{MrO}-5 \mathrm{CaO} \cdot 3 \mathrm{Al}_{2} \mathrm{O}_{3} \cdot$ . C. Hansen. J. Am. Chem. Soc., 50, 3081(1928).

The cause of unsoundness in portland cement. H. Lerch. Concrete - Cement Mill Edition (Concrete Publishing Co., 400 . Madison St., Chicago, IIl.), 35, I09(July 1829); 115 (AUE. 1929).

Calculation of comnounds in portland cement. R. H. Bokue. Ind. \& Eng. Chem. (Anal. Edition) (Industrial and Ineineering chemistry, nills Blas., lashington, D.C.), l, 192(0ct. 1929).

High strength, hish early strength, and waterproof concrete. P. H. Bates. Tners. and Eng. (Engineers and Ensineering Ceased publication vith vol. 49, Far. 1932), 46, 177 (Juiy 1929).

Variations in standard nortand cements. P. H. Bates Proc. Am. Concrete Inst. (Americśn Concrete Institute, 7400 Second BIVd., Detroit, Mich.), 26, 65(1930).

The relation between the strencths of cerrents developed by mortar snecimens and concrete snecimens. J. R. Dwyer and P. H. Bates. Proc. Ar. Soc. Testinc iraterials (Arerican Societ for Testin livterials, 330 . Broad St., Philadelnhia, Pa.), 30, Part II, 598(1930).

Some properties of high alumina cerent prom six countries. P. H. Bates. Proc. New Intern. Assoc. Testino iraterials (New Internatjonal Association for Testing Faterials, Leonhardstrasse 37, Zurich, Switzerland, Group B, 2IO(19.30).

Revised procedure for the determination of uncorbined lime in portland cement. Im. Lerch and $\mathrm{K}$. $\mathrm{i}$. Bogue. Ind. and Eng. Cher. (Anal. Edition) - (Industrial and EnEineering Cheristry, Mills Blag., Wasiington, D. C.), ㄹ, 296 (July $15,1930)$. 


\section{PART VI. - OUTSIDE TUBICAIONS (Continued)}

The I-ray nethod apolied to a study of the constitution of portland cement. I. T. Bromriller and R. H. Bogue. m. T. Sci. (American Journal of Science, iJew Haven, Conn.), 22, 241(1930); also BS T. Research 5, 81.3(1930), RP2.3.3.

Suggested investigations of him alumina cements. P. I. Bates. Hoc. New Intern. Issoc. Festing Haterials, (1931).

Cement and concrete. (Chapter XXVIII: Annual Survey of irerican Chemistry, 1830). John Tucker, ir. Annual Survey s. Cher. (IJational Research Council, Waskington, D.C.), ïay 1931.

Can cement durability be predicted: E. T. Carlson and P. H.

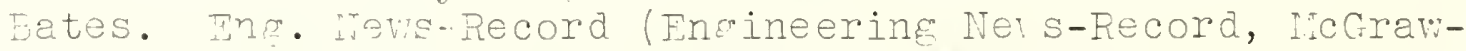
Hill publishing Co., $330 \mathrm{U}$. 42d St., IjeW York, iv. Y.), $107,130(141 \mathrm{y} 23,1931)$.

The decomposition of tricalcium silicate in the terperature rance $1000^{\circ}-1300^{\circ} \mathrm{C}$. $\mathrm{i}$. T. Carlson. Rock Products (Tradepress Publishing Corp., 205 V. Vacker Drive, Chicago, Ill.), XYYIT, 52, Dec.5, 1931; álso BS J. Fesearch 7, 893(1931), R.P.381.

Natural cenont mortar found strons efter half a century. P. H. Pates. TnE. Netis-Record, 108, $98(J a n .21,1932)$.

rotes on hardenin" cemnts at the boiling point of rater. P.F. Eates, and R. T. Blaine. Proo. Ar. Concrete Inst. (Arierican concrete Institute, 7400 Second Blvd., Detroit, Fich.), 28, $531(1932)$.

The syster CaO-NanO-AlgOz. I. I. Brommiller and L. it. Bogue. Am. T. Sci. (Anerican Jonmal of Srience, Mew Ileiven, Conn.), 233, 501 (1932); also BS J. Research 8, 289(193n), RP414.

The cherical analyses of the narticles of vious sizes of Eround corlent. T. T. Carlson and P. F. Bates. Kock Products, XXXT, 18, cot. 2\%, 1832.

The hydration of tricalcium aluminate. T. I. Foster. Proc. Am. Concrete Inst., 20, $189(1932)$.

jtatus of specifications for hyaraulic cerents in the United States. P. H. Bates. Proc. H. Soc. Testing Iatericils ( 260 S. Hroad st., Philadelphia, Pa.), 33, Part II, 40ं $(1933)$. 
A rapid method for deterrination of the specific surface of portlana cement. L. A. Wagner. Proc. Am. Soc. Testing Materials (260 S. Broad st., Philadelphia, Pa.), 33, Part II, $553(1933)$.

Present day cement and cement of 20 years ago. P. H. Bates. Ens. INews-Record (HoGraw-Hill Publishing Co., 330 . 42d St., New Tork, N. I.), 110, 492(1933).

A compilation of phase-rule diacrams of interest to the ceramist and silicate technologist. F. P. Hall and Herbert Insley. J. An. Ceran. Soc. (American Ceranic Society, 2525 Iv. High st., Colurbus, onio), If , $483(1933)$.

Progress renort on the reaction of calciur chlorice on portland cement. I. S. Wells and Paul Rapp. Proc. Highvay Research Board (Tarional Fesearch Council, Washin ton, D. C.) Thirteentin Annual jeetins, 201 (Lec. 19.33).

Heat of hydration of portland cenent pastes. Th. Iuerch and R. H. Bogue. Concrete - Cement rili section (concrete Publishing Co., 400 T. Madison St., Chicago, IIl.), 42, $36(1934) ; 39(1934) ;$ also J. Research INBS II, 645(1934), KP684.

A simple apnaratus for deteminine heat of nydration of portlana cement. Tm. Jerch. Eno. NTews-Record, 113, 523(1934).

Hydration of portland cement compounds. F. E. Bofue and 1 .m. Lerch. Ind, and Png. Chem. (Industricil and Engineering Chemistry, Mills Bldg., Tashington, D. C.), 26, 237 (1934).

Influence of composition on volume constancy and salt resistarce of portlard cerent pastes. F. H. Bogue, Tm. Lerch, and W. C. Tayzor. Ind, and Ing. Cher., 26, $1049(1934)$.

Effect of calciur chloride on portand cements and concretes. Paul Kapp. Proc. IIichway Research Board, Fourteenth Annucil Meeting, Dec. 1934.

Trends in the production and use of various types of hydraulic cenents. P. I. Bates. Proc. m. Concrete Inst. (Merican Concrete Irstitute, 7400 Second BIva., Detrit, Nich.) 31, $225(1935)$.

Compounds in portiaró cenent revealed by high-tenperature research upon cenent components. F. E. Bogue. Ind. 2c Ing. Cher., 27, 1312(1935). 


\section{PART VI. - OUTSIDE PUBLICATICNS (Continued)}

A study of the syster Iime-Potash-Alumina. I. T. Brownmiller. Am. J. Sci. (American. Journal of Science, New Haven, Conn.), 29, $260(1935)$.

Detemination of specific surface of portland cement raw mixtures by reans of Wagner turbidimeter. T. Asano. Rock Products (Tradepress Publishing Corp., 205 V. Tacker Drive, Chicago, Ill.), 39, Feb. 1936.

The use of blast furnace slags in the manufacture or hydraulic cements. P. H. Bates. Proc. Nat. Slag Assoc. (National Slac Association, Earle Bldg., Washington, D. C.), 1930.

Fffect of departure from planeness of bearing surfaces on the compressive strength of 2 -in. mortar cubes. J. R. Dwyer, Proc. Ar. Soc. Testing liaterials (Mmerican Society for Testing liaterials, 260 South Broad Street, Philadelphia, Pa.), 36, Part II, $351(1936)$.

Controlling the heat of hyaration of cements - P. H. Bates. proc. Internat'l Assn. for Testing liaterials, London Coneress, Apr. 19.37, p. 262.

IEthod for epproximating the olass content of Portland cenent clinker. Tr. Lerch and T. Brommiller (Paper i32, Portland Cement Association Fellovship, National Bureau of Standaras, Washington, D. C., lay 1937.

Some effects or heat treatment on portland cement clinirer. Tm. Ierch and C. Taylor. Portlend Cement Association Fellowship, (National Bureau of Standards, Mashington, J. C.) paperit33, July 1937; Concrete, I. S., 45, 198, 217(1937).

The Cement Reference Laboratory - J. F. Dwyer. A. S. T. I., Bull., IO. 87, I2(Aug. 1937).

Some sugrested practices in the estimation of particle size gradation of granular materials - T. R. Gran. A.S.T.I. Bull, No. 88, 17(oct. 1937); Pit \& quarry, 30, 1Jo. 10, 69(1938).

The hydrated calcium silicetes. E. P. Flint and Lansins s. Wells. Trans. Am. Geophysical Union (National Academy of Sciences, Wash., D. C.), part 1, 261(Dec. 1937).

The structure of the flassy phase of Portiand cement clinier I. T. Browmiller. Ar. J. Science, New Haven, Conn., 35, $241(1938)$.

Supplement to a corpilation of phase-rule diagrans of interest to the ceraric and silicate technolopist. E. P. Iall anà H. Insley. T. Ar. Ceraric Soc. (2525 N. High St., Columbus, ohio), 17, 10(ray 19.38). 
PART VI. - OUTSIDE PUBIICATIOIS (Continued)

Tffect of glass content unon the heat of hydration of portiand cement. Milliar Lerch. Paper ito. 36, Portlan? Cement Association Fellowship (National Bureau of Standards, Wash. D. C.) Aug. 1938.

Phase equilibria studies on nixtures of the compounds $4 \mathrm{CaO} \cdot \mathrm{Al}_{2} \mathrm{O}_{3} \cdot \mathrm{Fe}_{2} \mathrm{O}_{3}-2 \mathrm{CaO} \cdot \mathrm{Fe}_{2} \mathrm{O}_{3}-\mathrm{K}_{2} \mathrm{O} \cdot \mathrm{Al}_{2} \mathrm{O}_{3} \cdot \mathrm{W}$. C. Taylor. peper ITo. 37, Portiana Cerient Association Fellowship, Washington, D. C.), Sept. 1938.

Constitution of portland cement clinker - R. H. Bosue. Peprint from Proc. Smposium on Chemistry of Cerients (stockholn, Sweden) (1938).

Mineralizers in cerient - EP Flint. Rock Products 42, oct. 1939.

Theories (approved and oth rrise) and specifications for portlend cement - P. E. Bates. An abstract of the Idgrir raburg Jecture read before the unnual reeting of the Agri, in Atlantic City, June 20, 1940. Pitt and auary, 37 (sept. 1940).

oxides extracted in lierrinan's test of portland cement T. P. Flint and P. II. Bates. Rock Ploducts 43, no. 10, $4 \ddot{0}($ oct. 1940).

Studies of the measurement of specific surface by air pemesbility - RI Blaine. Bull. ASTI Ho. 108, Jen. 1941.

Potassium sulfate as a constituent of portiand cement clinkers G. I. Kalousek, C. H. Tumer, and J.J. Tresonins. Rock Products, fpril 1941. 
